\title{
Yeltsin raises pay for Russian scientists ...
}

Moscow. The Russian President, Boris Yeltsin, keen to stem the growing brain drain of scientific talent out of the country — and also to strengthen his political support in his bitter power struggle with parliament - has approved substantial salary increases for the country's leading scientists

As from 1 November, full members of the Russian Academy of Science will receive a stipend of 150,000 rubles (about US $\$ 1,100$ ) a month on top of their regular academic salaries. Corresponding members of the academy will receive a stipend of half this value, namely 75,000 rubles a month.

These figures compare to the current monthly stipends of 10,000 rubles for full members and 5,000 rubles for corresponding members. There will also be increases for qualified researchers and for postgraduate students. Each of these will now be paid an additional stipend equal to half their salaries, and worth about 60,000 and 30,000 rubles respectively.

In addition, Yeltsin also announced that, as from next January, the government will select 5,000 "outstanding Russian scientists" who will be paid monthly stipends of 75,000 rubles each, in addition to their regular salaries. Further stipends of 50,000 rubles will be awarded to a thousand "promising young researchers".

These salary increases to academy members and other scientists have been approved by Yeltsin in a decree issued two weeks ago at the suggestion of the president of the academy, Yuri Osipov, a close colleague of the Russian president since his days in Sverdlovsk.

The decision to award monthly stipends to individual scientists is widely seen as Yeltsin's response to the proposal that the government should establish a system of "state professors". The proposal was put forward by Vladimir Zakharov, director of the Landau Institute of Theoretical Physics and a prominent member of the academy. Its aim had been to make the status and stipends sufficiently attractive to persuade leading scientists to stay in Russia and thus to curtail the exodus of its scientific élite.

The need for such an initiative has increased as a result of the creation of bodies such as the International Science Foundation, established by the Hungarian-born financier George Soros. Because of their charitable status, all of these foundations have decided to restrict their help to those who are in most financial need.

In contrast, the country's scientific élite, most of whom are still able to enjoy a relatively satisfactory standard of living as a result of their contacts with the West, have been largely neglected by such foundations. As a result, many leading Russian scientists feel increasingly deprived of the

opportunity to work in their own country.

Zakharov and others argued that it was up to the state to correct this situation by creating a system such as that of "state professors", and that those awarded such a title be given a relatively generous stipend of about 120,000 rubles a month.

But the proposal has been opposed by the presidium of the academy, apparently worried that a new system of state professors would challenge its own authority. The opposition from the academy establishment had, until now, been one factor holding back any response from the Ministry of Science. But the new decree
implies that the $\begin{array}{cl}\text { IMAGE } & \begin{array}{l}\text { idea of state pro- } \\ \text { fessors has finally } \\ \text { obtained a legal } \\ \text { backing - even if } \\ \text { in a modified form }\end{array} \\ \text { COPYRIGH } & \begin{array}{l}\text { - as a result of } \\ \text { support from its } \\ \text { strongest adver- } \\ \text { sary. }\end{array}\end{array}$ According to

Boris Yeltsin: wooing scientists. Makarov, the scientific body is not opposed to the creation of state professors as such. And Andrei Gonchar, the academy's vicepresident, said at a press conference in Mos- cow that the new stipends should not be seen as an alternative to the idea of state professors as proposed by Zakharov.

But some observers are sceptical of this interpretation, as it seems unlikely that the government would support the simultaneous existence of 5,000 "outstanding scientists" and 5,000 "state professors", both supposed to enjoy the same scientific status but living on substantially different rates of pay.

At the current rate of inflation, the proposed stipends will have lost much of their value by January, and they are in any case only slightly higher than the official poverty level in cities such as Moscow and St Petersburg. It is therefore unlikely that, even though it will somewhat improve the financial situation of the impoverished Russian scientists, such an incentive will induce any truly outstanding Russian scientists to abandon the idea of emigration.

The decree appears to be linked to the recent instruction from Yeltsin to Osipov and the Minister of Science, Boris Saltykov, that they should present him within a month with suggestions on how the funding of science in Russia could be improved.

The main regret in the scientific community is that the new moves will not do enough to help the scientific élite. But more help is likely to come in a new decree from Yeltsin in response to a request from Osipov for more money for scientific equipment and laboratory supplies. Vladimir Pokrovsky

\section{... but OECD says it has too many}

Moscow. Russia's scientific community is three times larger than the country can currently afford to support, and should therefore take steps to reduce this number, according to the preliminary report of an expert panel set up by the Organization for Economic Cooperation and Development (OECD).

Based on an evaluation carried out at the beginning of this year, the OECD experts concluded that Russia is able to support at most 300,000 scientists and engineers. The report points out that so far between 200,000 and 300,000 posts have been cut, and that further large cuts lie ahead.

The OECD evaluation was carried out with the support of Russia's Minister of Science, Boris Saltykov. The group toured most of Russia's main scientific establishments, and prepared a report containing an analysis of the current situation and recommendations for action.

The report, which was discussed at a closed meeting with Russian officials in Moscow last week, gives high marks to the various steps taken by the Ministry of Science for the recovery of Russian science, such as the establishment of the Russian
Foundation of Basic Research and the creation of a network of scientific centres.

Specific recommendations included the need to create a state-level interdepartmental coordinating organization, to address the "brain drain", and to make the institutional changes that are necessary to shift the emphasis of the research community from the military-directed science to its civilian applications.

According to Saltykov, most of these recommendations "are in line with the decisions on which the Ministry of Science bases its policies". But he was less happy about the remarks that Russia has too many scientists - even though he has expressed similar opinions in the past - arguing that this was "a political question".

Saltykov, along with most of the scientific community, believes that it would be impossible to make drastic cuts at this time, partly because of the social dislocation they could cause in the scientific community

The final report of the expert group's evaluation is expected to be completed in a few months, but it is not likely to differ substantially from the present version.V.P. 